\title{
PENINGKATAN PENDAPATAN PERAJIN GULA MELALUI AGROINDUSTRI GULA SEMUT DI KABUPATEN TASIKMALAYA
}

\author{
Oleh \\ CECEP PARDANI \\ Fakultas Pertanian Universitas Galuh Ciamis \\ Email: alfarhanic@gmail.com
}

\begin{abstract}
Abstrak
Desa Cikuya merupakan salah satu desa yang berada di Kecamatan Culamega Kabupaten Tasikmalaya, dimana penduduknya telah melakukan suatu inovasi dalam rangka meningkatkan pendapatanya dengan cara membuat gula semut. Pembuatan gula semut itu merupakan yang pertama kali ada di Kabupaten Tasikmalaya. Gula semut adalah hasil turunan dari gula cetak. Gula semut ini murni tanpa campuran bahan apapun, sehingga rasanya juga sangat khas aroma aren. Butiran yang lembut, warna yang coklat, aroma khas aren memberikan dampak yang baik bagi makanan dan minuman yang dicampurkannya. Penelitian ini dilaksanakan dengan tujuan untuk mengetahui: 1) Besarnya biaya pada agroindustri gula semut per satu kali proses produkis di Kabupaten Tasikmalaya, 2) Besarnya penerimaan dan pendapatan pada agroindustri gula semut per satu kali proses produkis di Kabupaten Tasikmalaya. 3) Besarnya R/C pada agroindustri gula semut per satu kali proses produkis di Kabupaten Tasikmalaya. Metode yang digunakan adalah metode survai yang berlokasi di Desa Cikuya Kecamatan Culamega Kabupaten Tasikmalaya. Penentuan lokasi dan sasaran penelitian yang dilakukan dengan menggunakan purposive sampling terhadap kelompoktani aren yang berjumlah 19 orang. Rancangan analisis data yang digunakan adalah analisis tentang biaya, penerimaan, pendapatan dan R/C pada agroindustri gula aren per satu kali proses produksi. Hasil penelitian menunjukkan bahwa:

1) Rata-rata besarnya biaya agroindustri gula semut per satu kali proses produksi di Kabupaten Tasikmalaya adalah Rp. 300.091,89, yang terdiri dari biaya tetap sebesar Rp. 78.021 .89 dan biaya variabel sebesar Rp. 333.070,00.

2) Rata-rata besarnya penerimaan agroindustri gula semut per satu kali proses produksi di Kabupaten Tasikmalaya adalah Rp. 590.200,00 dan besarnya nilai pendapatan adalah Rp. 290.108,11.

3) Rata-rata besarnya R/C agroindustri gula semut per satu kali proses produksi di Kabupaten Tasikmalaya 1,97. Ini mempunyai artinya, bahwa setiap pengeluaran biaya produksi Rp. 1 dapat menghasilkan penerimaan sebesar Rp 1,97 sehingga diperoleh pendapatan sebesar Rp 0,97. Berdasarkan hal tersebut, maka agroindustri gula semut di Kabupaten Tasikmalaya menguntungkan dan layak untuk diusahakan.
\end{abstract}

Kata kunci: agroindustri, gula semut, biaya, penerimaan, pendapatan, $\mathrm{R} / \mathrm{C}$

\section{PENDAHULUAN}

Pembangunan Pertanian di Indonesia tetap dianggap terpenting dari keseluruhan pembangunan ekonomi, apalagi semenjak sektor pertanian ini menjadi penyelamat perekonomian nasional karena justru pertumbuhannya meningkat, sementara sektor lain pertumbuhannya menurun. Beberapa alasan yang mendasari pentingnya pertanian di Indonesia : (1) potensi sumberdayanya yang besar dan beragam, (2) devisa terhadap pendapatan nasional cukup besar, (3) besarnya penduduk yang menggantungkan hidupnya pada sektor ini dan (4) menjadi basis pertumbuhan di perdesaan (Saragih, 2004).
Potensi pertanian yang besar namun sebagian besar dari petani banyak yang termasuk golongan miskin adalah sangat ironis terjadi di Indonesia. Hal ini mengindikasikan bahwa pemerintah bukan saja kurang memberdayakan petani tetapi sektor pertanian keseluruhan. Disisi lain adanya peningkatan investasi dalam pertanian yang dilakukan oleh investor Pemilik Modal Asing (PMA) dan Pemilik Modal Dalam Negeri (PMDN) yang berorientasi pada pasar ekspor umumnya padat modal dan perananya kecil dalam penyerapan tenaga kerja atau lebih banyak menciptakan buruh tani (Saragih, 2004). 


\section{MIMBAR \\ A GRIBISNIS}

ISSN 2460-4321

Volume 1・ Nomor 1・Juli 2015

Beberapa arah kebijakan pembangunan pertanian Republik Indonesia Tahun 2010-2014 sebagai berikut (Agribisnis Unisma, 2010) :

a. Swasembada berkelanjutan untuk beras, jagung, daging ayam, telur, dan gula konsumsi, serta peningkatan produktivitas guna mencapai swasembada kedelai, daging sapi, dan gula industri. Dalam waktu bersamaan, memperkuat basis produksi susu segar, buah lokal, dan komoditas unggulan nasional lainnya.

b. Mendorong minat investasi pertanian dan kemitraan usaha melalui promosi yang intensif dan dukungan iklim usaha yang kondusif.

c. Pembangunan kawasan komoditas unggulan terpadu secara vertikal dan/atau horizontal dengan konsolidasi usahatani produktif berbasis lembaga ekonomi masyarakat yang berdaya saing tinggi di pasar lokal maupun internasional.

d. Pengembangan diversifikasi pangan dan pembangunan lumbung pangan masyarakat untuk mengatasi rawan pangan dan stabilisasi harga di sentra produksi.

e. Pengembangan industri hilir pertanian di perdesaan yang berbasis kelompok tani untuk meningkatkan nilai tambah dan daya saing produk pertanian, membuka lapangan kerja, mengurangi kemiskinan, dan meningkatkan keseimbangan ekonomi desa-kota.

Kabupaten tasikmalaya merupakan daerah yang kaya sumber bahan alam salah satunya adalah aren. Aren atau enau (Arenga pinnata Merr.) adalah salah satu keluarga palma yang memiliki potensi ekonomi yang tinggi dan dapat tumbuh sumbur di wilyah tropis Indonesia. Adanya potensi bahan baku yang cukup besar memberi peluang dilakukannya diversifikasi agroindustri di Indonesia (Asia Pacipic Coconut Communit, 2003).

Agroindustri merupakan bagian integral dari pembangunan sektor pertanian. Efek agroindustri mampu mentranformasikan produk primer ke produk olahan sekaligus budaya kerja bernilai tambah rendah menjadi budaya kerja industrial modern yang menciptakan nilai tambah tinggi (Suryana, 2005).

Masyarakat pada umumnya, sudah lama mengenal pohon aren sebagai pohon yang dapat menghasilkan bahan-bahan industri. Hampir semua bagian tanaman ini dapat dimanfaatkan. Buahnya dapat dibuat kolang kaling, daunnya sebagai bahan pembuatan atap, batangnya sebagai bahan sagu dan bahan bangunan, serta akarnya sebagai bahan untuk obat. Namun dari semua bagian aren, nira aren yang berasal dari bunga jantan sebagai bahan baku untuk gula aren adalah yang paling besar nilai ekonomisnya (Rachman dan Benny, 2005).

Gula aren sudah dikenal oleh masyarakat sebagai salah satu pemanis makanan dan minuman yang bisa menjadi substitusi gula pasir (gula tebu). Gula aren diperoleh dari proses penyadapan nira aren yang kemudian dikurangi kadar airnya hingga menjadi padat. Produk gula aren ini adalah berupa gula cetak dan gula semut (Rachman dan Benny, 2005).

Kabupaten Tasikmalaya merupakan salah satu kebupaten penghasil gula aren di Jawa Barat. Dari 23 kecamatan penghasil gula aren yang ada di Kabupaten Tasikmalaya hanya di Kecamatan Culamega terdapat perajin yang membuat gula semut tepatnya di Desa Cikuya. Di Desa Cikuya hanya terdapat satu kelompok yang melakukan inovasi dalam agroindustri gula semut yaitu Kelompoktani Aren yang merupak satu-satunya kelompok vionir yang membuat gula aren di Kabupaten Tasikmalaya (Dinas Koperasi, Perindustrian dan Perdagangan Kabupaten Tasikmalaya, 2012).

Kegiatan agroindustri gula semut dalam pelaksanannya tidak terlepas dari biaya produksi. Penggunaan biaya ini dimaksudkan untuk meningkatkan nilai tambah dari komoditas gula cetak, serta untuk meningkatkan pendapatan keluarga juga membuka lapangan pekerjaan bagi masyarakat sekitarnya.

Penelitian ini dilaksanakan dengan tujuan untuk mengetahui :

1) Besarnya biaya agroindustri gula semut per satu kali proses produksi di Kabupaten Tasikmalaya.

2) Besarnya penerimaan dan pendapatan agroindustri gula semut per satu kali proses produksi di Kabupaten Tasikmalaya.

3) Besarnya R/C agroindustri gula semut per satu kali proses produksi di Kabupaten Tasikmalaya. 


\section{Peningkatan Pendapatan Perajin Gula Melalui Agroindustri Gula Semut \\ di Kabupaten Tasikmalaya \\ CECEP PARDANI}

\section{KAJIAN PUSTAKA}

Menurut Soetriono dan Anik (2006) Agroindustri diartikan sebagai semua kegiatan industri yang terkait erat dengan kegiatan pertanian. Agroindustri mencakup beberapa kegiatan antara lain sebagai berikut :

1. Industri pengolahan hasil pertanian dalam bentuk setengah jadi dan produk akhir

2. Industri penanganan hasil pertanian segar

3. Industri pengadaan sarana produksi pertanian

4. Industri pengadaan alat-alat pertanian dan agroindustri lainnya.

Menurut Saragih (2010) sektor agroindustri adalah industri yang memiliki keterkaitan ekonomi (baik langsung maupun tidak langsung) yang kuat dengan komoditas pertanian. Keterkaitan langsung mencakup hubungan komoditas pertanian sebagai bahan baku (input) bagi kegiatan agroindustri maupun kegiatan pemasaran dan perdagangan yang memasarkan produk akhir agroindustri. Sedangkan keterkaitan tidak langsung, berupa kegiatan ekonomi lain yang menyediakan bahan baku (input) di luar komoditas pertanian, seperti bahan kimia, bahan kemasan, dan lain-lain, beserta kegiatan ekonomi yang memasarkan dan memperdagangkannya.

Soekartawi (2005) menyatakan biaya adalah nilai dari seluruh penggunaan sarana produksi (input) dan lain-lain yang diperlukan atau dibebankan pada proses produksi yang bersangkutan.

Rahim dan Hastuti (2007) menyatakan biaya terbagi dua yaitu biaya tetap dan biaya variabel. Biaya tetap adalah biaya yang dikeluarkan untuk mendapatkan faktor-faktor produksi atau input yang tidak dapat diubah jumlahnya dalam jangka pendek dan besarnya biaya tetap tidak tergantung pada jumlah produk yang dihasilkan. Adapun yang termasuk biaya tetap yaitu Pajak Bumi dan Bangunan ,Penyusutan alat dan bangunan, Pajak perijinan dan Bunga modal dari biaya tetap. Biaya variabel adalah biaya yang digunakan untuk membeli atau menyediakan bahan baku yang habis dalam satu kali produksi.

Penerimaan menurut Soekartawi (2006) menyatakan penerimaan adalah sesuatu yang dihasilkan dari adanya suatu tindakan ekonomi berupa penjualan produk. Penerimaan dapat diketahui dengan mengalikan jumlah produksi total dengan harga produk tersebut (Hastuti dan
Rahim, 2007). Pendapatan adalah selisih antara antara penerimaan dengan semua biaya.

Soekartawi (2002) menyatakan, bahwa untuk mengetahui tingkat kelayakan suatu cabang usaha, salah satunya dapat di lihat dengan analisis imbangan antara penerimaan dengan biaya produksi atau revenue cost ratio (R/C). 1) apabila nilai R/C lebih besar dari satu, maka usaha tersebut menguntungkan dan layak diusahakan. 2) apabila nilai $\mathrm{R} / \mathrm{C}$ sama dengan satu, maka usaha tersebut tidak memperoleh keuntungan dan tidak menderita kerugian (impas). 3) apabila nilai R/C kurang dari satu, maka usaha tersebut mengalami kerugian dan tidak layak untuk diusahakan.

Menurut Badan Penelitian Tanaman Palma (2010), gula semut adalah gula merah berbentuk serbuk, beraroma khas, dan berwarna kuning kecoklatan. Proses pengolahan gula semut sama dengan pengolahan gula cetak, yaitu tahap pemanasan nira hingga menjadi kental. Pada pengolahan gula cetak, setelah diperoleh nira kental, wajan diangkat dari tungku, dilakukan pencetakan, sedangkan pada pengolahan gula semut setelah diperoleh nira kental dilanjutkan dengan pendinginan dan pengkristalan. Pengkristalan dilakukan dengan cara pengadukan menggunakan garpu kayu. Pengadukan dilakukan secara perlahanlahan, dan makin lama makin cepat hingga terbentuk serbuk gula (gula semut).

Langkah selanjutnya adalah pengeringan gula semut. Pengeringan dilakukan dengan dua cara, yaitu (1) pengeringan dengan sinar matahari selama 3-4 jam dan (2) pengeringan dengan oven dengan suhu pengeringan $45^{\circ} \mathrm{C}-50^{\circ} \mathrm{C}$ selama $1,5-2,0$ jam. Untuk keseragaman ukuran butiran, dilakukan pengayakan I menggunakan ayakan stainless steel ukuran 18-20 mesh. Butiran gula yang tidak lolos ayakan akan dikeringkan ulang dan dilanjutkan dengan penghalusan butiran. Penghalusan ukuran butiran dengan grinder mekanis, diikuti dengan pengayakan II. Gula semut kering dikemas dalam kantong plastik dengan ukuran berat bervariasi, yaitu 250 gram, 500 gram dan 1000 gram $(1 \mathrm{~kg})$.

Cara pengolahan gula semut tersebut telah dikembangkan oleh koperasi petani di Desa Hariang, Kabupaten Lebak, Provinsi Banten. Pengembangan agroindustri gula semut model Hariang dimulai sejak tahun 2000. Pengolahan gula semut di Desa ini 


\section{AIMBAR \\ A GRIBISNIS \\ ISSN 2460-4321}

Volume 1・ Nomor 1・Juli 2015

dilakukan dalam dua tahap, yakni tahap pertama pengolahan dilakukan anggota kelompok tani/koperasi, menghasilkan gula semut kasar, dan tahap kedua pengolahan lanjut pada unit pengolahan di koperasi dihasilkan gula semut.

Pengolahan pada tingkat koperasi, dengan kegiatan meliputi pengeringan, pengayakan dan pengepakan. Pengeringan gula semut dilakukan dengan dua cara, yakni dengan sinar matahari dan dalam oven sistem rak $(70 \%$ produk dikeringkan dengan oven dan 30\% dengan sinar matahari). Pengayakan secara manual dengan saringan ayakan stainles steel 18-20 mesh. Produk dikemas dalam karung propilien dua lapis beratnya $50 \mathrm{~kg} / \mathrm{karung}$. Gula semut hasil olahan dengan karakteristik: kadar air 2.88\%, kadar sakarosa 92.02\%, cemaran logam $\mathrm{Pb}$ kurang dari $0.05 \mathrm{ppm}$ dan kadar abu $1.35 \%$. Gula semut yang dihasilkan Koperasi Usaha Bersama Mandala Hariang, memenuhi syarat mutu SII.

\section{METODE PENELITIAN}

Metode penelitian yang digunakan adalah metode survai, dengan mengambil kasus di Desa Cikuya Kecamatan Culamega Kabupaten Tasikmalaya. Metode survai adalah penelitian yang mengambil sampel dari satu populasi dan menggunakan kuesioner sebagai alat pengumpulan data yang pokok (Daniel, 2003).

Lokasi penelitian ini ditetapkan secara disengaja (Purposive) yaitu di Desa Cikuya Kecamatan Culamega Kabupaten Tasikmalaya dengan pertimbangan hanya terdapat satusatunya kelompok yang melakukan agroindustri gula semut. Sasaran penelitian adalah responden yang merupakan anggota kelompok agroindustri gula semut yang berjumlah 19 orang.

Data yang dikumpulkan dalam penelitian ini meliputi data primer dan data sekunder. Sedangkan sumber data dalam penelitian ini adalah anggota kelompok agroindustri gula aren, perpustakaan, Dinas Pertanian Kabupaten Tasikmalaya, BPP Kecamatan Culamaega dan Kantor Desa Cikuya.

Teknik pengumpulan data primer dilakukan dengan cara wawancara langsung terhadap responden dengan menggunakan daftar pertanyaan (kuesioner) yang telah dipersiapkan terlebih dahulu. Sedangkan pengumpulan data sekunder dilakukan melalui studi pustaka dan kunjungan ke Dinas atau Instansi terkait (Dinas Pertanian, BPP, Kantor Desa, Perpustakaan dan lain-lain).

Untuk menentukan besarnya biaya total, penerimaan, pendapatan dan $\mathrm{R} / \mathrm{C}$ dihitung dengan rumus sebagai berikut :

1. Analisis Biaya

Menurut Rahim dan Hastuti (2007), menghitung biaya total (Total Cost) diperoleh dengan cara menjumlahkan biaya tetap total (Total Fixed Cost/TFC) dengan biaya variabel total (Total Variable Cost) dengan rumus:

$\mathrm{TC}=\mathrm{TFC}+\mathrm{TVC}$

di mana :

$\mathrm{TC}=$ Total cost (biaya total)

TFC $=$ Total fixed cost (biaya tetap total)

$\mathrm{TVC}=$ Total variable cost (biaya variabel total)

2. Analisis Penerimaan

Secara umum perhitungan penerimaan total

(Total Revenue/TR) adalah jumlah total produksi dikalikan dengan harga jual satuan produksi dan dinyatakan dalam rumus berikut :

TR = Hy . Y

di mana

$\mathrm{TR}=$ Total revenue (penerimaan total)

$\mathrm{Y}=$ kuantitas (volume penjualan)

Hy = Price (harga jual)

3. Analisis Pendapatan

Pendapatan adalah penerimaan total (Total

Revenue/TR) dikurangi dengan biaya total

(Total Cost/TC) digunakan rumus sebagai berikut :

$\pi=\mathrm{TR}-\mathrm{TC}$

di mana

$\pi=$ pendapatan

$\mathrm{TR}=$ Total revenue (penerimaan total)

$\mathrm{TC}=$ Total cost (biaya total)

4. Untuk mengetahui besarnya $\mathrm{R} / \mathrm{C}$ dihitung dengan menggunakan rumus sebagai berikut :

$$
\begin{aligned}
& \mathrm{R} / \mathrm{C}=\frac{\mathrm{TR}}{\mathrm{TC}} \\
& \text { di mana } \\
& \mathrm{R} / \mathrm{C}=\text { Rasio } \\
& \mathrm{TR}=\text { Total revenue (penerimaan total) } \\
& \mathrm{TC}=\text { Total cost (biaya total) }
\end{aligned}
$$




\section{Peningkatan Pendapatan Perajin Gula Melalui Agroindustri Gula Semut \\ di Kabupaten Tasikmalaya \\ CECEP PARDANI}

berikut:

Dengan ketentuan-ketentuan sebagai

a) $\mathrm{R} / \mathrm{C}$ lebih dari 1 , maka agroindustri gula semut menguntungkan

b) R/C sama dengan 1, maka agroindustri tersebut tidak rugi juga tidak untung (impas)

c) $\mathrm{R} / \mathrm{C}$ kurang dari 1 , maka agroindustri gula semut itu rugi.

\section{HASIL DAN PEMBAHASAN Pengolahan Gula Semut}

1. Bahan dan Peralatan Yang Dipakai

Bahan utama yang dipakai dalam pembuatan gula semut adalah nira aren atau dari gula aren yang setengah jadi. Sedangkan peralatan yang biasa digunakan dalam pembuatan gula semut ini terdiri dari pisau sadap, bambu sebagai penampung nira aren, katel, pengaduk dari kayu, tungku, saringan nira pemukul (peninggur), serok, nampan, ember, ayakan bambu (pengayak), potongan-potongan bambu atau tempurung kelapa dan kayu bakar, gayung, golok, seler, penghalus, sendok dan sendok besi.

2. Urutan Kerja

Tata urutan pembuatan gula semut adalah sebagai berikut:

1) Untuk pembuatan gula semut pertama yang diperlukan adalah nira segar, warna bening kekuningan dan berbau harum.

2) Untuk mendapatkan bahan baku gula semut yang prima, nira hasil pengumpulan langsung dididihkan dalam wajan.

3) Selama proses pemasakan api harus dijaga jangan sapai terlalu besar, agar adonan tidak tumpah keluar kuali. Tujuan dari penggodogan adalah menguapkan kandungan air sehingga yang tersisa adalah sirup gula kental.

4) Tanda-tanda sirup gula sudah kental adalah membutuhkan tenaga ekstra saat mengaduk. Sampai tahap ini terjadi perbedaan perlakun antara gula cetak dengan gula semut. Untuk gula cetak adonan yang telah mengental langsung dimasukan kedalam cetakan baik dari potongan bambu ataupun tempurung kelapa.

5) Sementara untuk gula semut ada perlakuan khusus yaitu didiamkan dulu, setelah agak dingin baru diaduk-aduk kembali. Pengadukan dilakukan dua kali dalam wajan yang sama. Pertama dengan menggunakan pengaduk dari kayu sampai gula itu mengkristal. Kedua diteruskan dengan diaduk-aduk oleh pengaduk yang terbuat dari bagian punggung tempurung kelapa dengan tujuan supaya kristal-kristal gula lebih halus dan merata.

3. Pengemasan dan Penyimpanan

Pengemasan gula semut dilakukan dengan cara membungkus dengan plastik. Agar kualitas gula semut dapat terjamin dan tahan lama perlu disimpan pada tempat yang relatif aman dari berbagai gangguan terutama gangguan dari hama tikus, dan dalam tempat yang kering serta tidak terkena cahaya matahari.

\section{Analisis Agroindustri Gula Semut 1. Biaya Total}

Rata-rata biaya total yang dikeluarkan Kelopoktani Aren selama menjalankan usahanya per satu kali proses produksi adalah sebesar Rp 300.091,89 yang terdiri dari :

\section{1) Biaya Tetap}

Biaya tetap yang dihitung dalam penelitian ini berupa pajak bumi dan bangunan (PBB), penyusutan alat dan bunga modal. Besarnya biaya tetap yang dikeluarkan masing-masing responden berbeda-beda. Hasil perhitungan rata-rata biaya tetap per satu kali proses produksi sebesar Rp. 78.021,89. Untuk lebih jelasnya dapat dilihat pada Tabel 1 .

Tabel 1. Rata-rata Besarnya Biaya Tetap Agroindustri Gula Semut Per Satu Kali Proses Produksi di Desa Cikuya Tahun 2012

\begin{tabular}{|c|c|c|}
\hline No. & Jenis Biaya & Besar (Rp) \\
\hline 1. & $\begin{array}{l}\text { Pajak Bumi dan } \\
\text { Bangunan }\end{array}$ & $5.000,00$ \\
\hline 2. & Penyusutan Alat & $68.605,56$ \\
\hline 3. & Bunga Modal & $4.416,33$ \\
\hline & Jumlah & 78.021.89 \\
\hline
\end{tabular}

Tabel 1 menunjukkan bahwa rata-rata pajak bumi dan bangun yang dibayarkan perajin agroindustri gula semut per satu kali proses produksi sebesar Rp. 5.000,00. Sedangkan besarnya biaya penyusutan alat dipengaruhi oleh jenis dan banyaknya alat yang digunakan dan dimiliki responden dalam agroindustri gula semut. Jenis alat yang digunakan meliputi : Lodong, tungku, gayung, ember, wajan, penyaring, pengaduk kayu, pisau sadap, golok, seler, timbangan, penghalus, pengayak, nampan, sendok, dan sendok besi. Rata-rata besarnya biaya penyusutan alat per satu kali 


\section{MIMBAR \\ A GRIBISNIS \\ ISSN 2460-4321}

Volume 1・ Nomor 1・Juli 2015

proses produksi adalah Rp. 68.605,56. Sedangkan bunga modal tetap dipengaruhi oleh besarnya bunga bank yang berlaku pada saat penelitian. Bunga yang digunakan dalam penelitian ini adalah bunga Bank Rakyat Indonesia( BRI ) setempat sebesar 18 persen per tahun atau 0,06 persen per satu kali proses produksi.

2) Biaya Variabel

Biaya variabel yang dihitung dalam penelitian ini meliputi air nira, kayu bakar, kemasan, label, jahe, tenaga kerja, dan bunga modal variabel. Hasil perhitungan memperlihatkan bahwa rata-rata besarnya biaya variabel yang dikeluarkan responden agroindustri gula semut per satu kali proses produksi sebesar Rp 222.070,00. Untuk lebih jelasnya dapat dilihat pada Tabel 2.

Tabel 2. Rata-rata Besarnya Biaya Variabel Agroindustri Gula Semut per satu Kali Proses Produksi di Desa Cikuya Tahun 2012

\begin{tabular}{|c|l|c|}
\hline No. & Jenis Biaya & Besar $($ Rp) \\
\hline 1. & Air Nira & $60.000,00$ \\
2. & Kayu Bakar & $40.000,00$ \\
3. & Kemasan & $10.000,00$ \\
4. & Label & $2.000,00$ \\
5. & Jahe & $12.500,00$ \\
6. & Tenaga Kerja & $75.000,00$ \\
7. & Bunga Modal & $12.570,00$ \\
\hline \multicolumn{2}{|c|}{ Jumlah } & $\mathbf{2 2 2 . 0 7 0 , 0 0}$ \\
\hline
\end{tabular}

Tabel 2 menunjukkan bahwa rata-rata besarnya biaya air nira per satu kali proses produksi adalah Rp. 60.000,00. Sedangkan untuk besarnya biaya kayu bakar yang dibutuhkan adalah Rp. 40.000,00, kemasan Rp. $10.000,00$, label Rp. 2.000,00, jahe Rp. 12.500,00, tenaga kerja sebesar Rp. 75.000,00 dan bunga modal variabel sebesar $R p$. 12.570.00. Bunga modal variabel ditentukan oleh besarnya bunga bank yang berlaku pada saat penelitian. Bunga yang digunakan dalam penelitian ini adalah bunga Bank Rakyat Indonesia (BRI) setempat sebesar 18 persen per tahun.

\section{Analisis Pendapatan}

Pendapatan merupakan selisih antara penerimaan dengan biaya total yang dikeluarkan, sedangkan penerimaan merupakan hasil perkaliaan antara harga jual dengan jumlah produk. Berdasarkan hasil penelitian harga jual produk pada saat penelitian adalah Rp 20.000,00 per kilogram, sedangkan rata-rata gula semut yang dihasilkan per satu kali proses produksi sebesar 29,51 kilogram, sehingga didapat penerimaan sebesar Rp. 590.200,00. Untuk lebih jelasnya mengenai rata-rata biaya total, jumlah produksi, penerimaan dan pendapatan dapat dilihat pada Tabel 3 .

Tabel 3. Rata-rata Jumlah Produksi, Harga jual per kilogram, Penerimaan, Biaya Total dan

Pendapatan Agroindustri Gula semut per Satu Kali Proses Produksi di Desa Cikuya Tahun 2012

\begin{tabular}{|c|l|c|}
\hline No. & \multicolumn{1}{|c|}{ Jenis Biaya } & $\begin{array}{c}\text { Agroindustri Gula } \\
\text { Semut (Rp) }\end{array}$ \\
\hline 1. & Jumlah Produksi & 29,51 \\
2. & Harga per & 20.000 \\
& kilogram & $590.200,00$ \\
3. & Penerimaan & $300.091,89$ \\
4. & Biaya Total & $290.108,11$ \\
5. & Pendpatan & \\
\hline
\end{tabular}

Tabel 3 menunjukkan bahwa besarnya rata-rata pendapatan agroindustri gula semut per satu kali proses produksi adalah $\mathrm{Rp}$. $290.108,11$.

\section{Analisis R/C Agroindustri Gula Semut}

$\mathrm{R} / \mathrm{C}$ (Revenue per Cost) adalah perbandingan antara jumlah penerimaan total dengan biaya total. Untuk lebih jelasnya dapat dilihat pada Tabel 4 .

Table 4. Rata-rata Biaya, Penerimaan, dan R/C Agroindustri Gula semut per Satu Kali Proses Produksi di Desa Cikuya Tahun 20012

\begin{tabular}{|c|l|c|}
\hline No & \multicolumn{1}{|c|}{ Uraian } & Jumlah \\
\hline 1. & Biaya & $300.091,89$ \\
2. & Penerimaan & $590.200,00$ \\
3. & R/C & 1,97 \\
\hline
\end{tabular}

Tabel 4 menunjukkan bahwa rata-rata besarnya biaya total pada agroindustri gula semut per satu kali proses produksi adalah Rp. 300.091,89, sedangkan rata-rata besarnya penerimaan total pada agroindustri gula semut per satu kali proses produksi adalah $\mathrm{Rp}$. 590.200,00 sehingga didapat rata-rata besarnya $\mathrm{R} / \mathrm{C}$ pada agroindustri gula semut per satu kali proses produksi sebesar 1,92. Nilai R/C sebesar 1,92 mempunyai arti, bahwa setiap pengeluaran biaya sebesar Rp. 1,00 akan mendapatkan 


\section{Peningkatan Pendapatan Perajin Gula Melalui Agroindustri Gula Semut \\ di Kabupaten Tasikmalaya \\ CECEP PARDANI}

penerimaan sebesar Rp. 1,92,00 dan pendapatan sebesar Rp. 0,92,00. Berdasarkan hal itu nilai $\mathrm{R} / \mathrm{C}$ lebih dari 1, maka agroindustri gula semut layak untuk diusahakan dan dikembangkan.

\section{PENUTUP}

\section{Simpulan}

Berdasarkan hasil dan pembahasan, maka dapat ditarik simpulan sebagai berikut :

1) Rata-rata besarnya biaya agroindustri gula semut per satu kali proses produksi di Kabupaten Tasikmalaya adalah Rp. $300.091,89$, yang terdiri dari biaya tetap sebesar Rp. 78.021.89 dan biaya variabel sebesar Rp. 333.070,00.

2) Rata-rata besarnya penerimaan agroindustri gula semut per satu kali proses produksi di Kabupaten Tasikmalaya adalah $\mathrm{Rp}$. 590.200,00 dan besarnya nilai pendapatan adalah Rp. 290.108,11.

3) Rata-rata besarnya $R / C$ agroindustri gula semut per satu kali proses produksi di Kabupaten Tasikmalaya 1,97. Ini mempunyai artinya, bahwa setiap pengeluaran biaya produksi Rp. 1 dapat menghasilkan penerimaan sebesar Rp 1,97 sehingga diperoleh pendapatan sebesar Rp 0,97 . Berdasarkan hal tersebut, maka agroindustri gula semut di Kabupaten Tasikmalaya menguntungkan dan layak untuk diusahakan.

\section{Saran}

Berdasarkan simpulan, maka disarankan kepada perajin gula semut pada Kelompoktani Aren di Desa Cikuya Kecamatan Culamega Kabupaten Tasikmalaya sebagai berikut :

1. Dengan melihat nilai $\mathrm{R} / \mathrm{C}$ yang cukup tinggi yaitu 1,97 yang artinya menguntungkan, disarankan kepada perajin gula semut untuk mempertahankan dan meningkatkan kegiatan usahanya serta melakukan inovasi baru.

2. Sebaiknya Kelompoktani Aren harus bisa memanfaatkan media on line dalam rangka mempromosikan gula arennya.

\section{DAFTAR PUSTAKA}

APCC, 2003. Coconut statistical year book 2002. Asia Pacipic Coconut Communit.

BPP Kecamatan Culamega. 2012. Laporan Tahunan Balai Penyuluhan Pertanian
Kecamatan Culamega Tahun 2012. Tasikmalaya.

Desa Cikuya. 2012. Monografi Desa Cikuya Tahun 2012. Cikuya.

Daniel, M. 2003. Metode Penelitian Sosial Ekonomi Pertanian bumi Aksara. Jakarta.

Dinas Koperasi Perindustrian dan Perdagangan Kabupaten Tasikmalaya. 2010. Potensi Industri Gula Aren. Dinas KOPERINDAG. Tasikmalaya

Http:// Agribisnis Unisma.blogspot.com /2010/06/ arah-kebijakan-pembangunanpertanian-ri. html. diakses 26 Agustus 2013

Http://balitka.litbang.deptan.go.id/index.php?op tion $=$ com_content $\&$ view $=$ article $\&$ id $=148$ $\% 3$ Agula-semut $\&$ catid=46\%3 Apaketteknologi-pascapanen $\&$ Itemid $=80 \&$ lang=en. Diakses 23 desember 2013.

Rachman dan Benny. 2005. Kajian Sosial Ekonomi Gula Aren. Badan Pengkajian Teknologi Pertanian (BPTP). Banten.

Rahim, A dan Hastuti, D. 2007. Pengantar Teori dan Kasus Ekonomika Pertanian. Penebar Swadaya. Jakarta.

Saragih, B. 2004, Perkembangan Mutakhir Pertanian Indonesia Dan Agenda Pembangunan Ke Depan. Jurnal Sosial Ekonomi Pertanian. Fakultas Pertanian Universitas Brawijaya Malang. 2010. Suara dari Bogor Membangun Opini Sistem Agribisnis. IPB Press. Bogor.

Soekartawi. 2002. Teori Ekonomi Produksi (Dengan Pokok Bahasan Analisis Fungsi Produksi Cobb Douglas). Rajawali. Jakarta. 2005. Analisis Usahatani. PT Raja Grafindo Persada. Jakarta.

Soetriono dan Anik. 2006. Agraris, Agrobisnis, dan Industri. Bayu Media. Jember.

Suratiyah, K. 2006. Ilmu Usaha Tani. Penebar Swadaya. Jakarta.

Suryana, A. 2005. Arah, Strategi dan Program Pembangunan Pertanian 2005-2009. Badan Penelitian dan Pengembangan Pertanian. Departemen Pertanian. Jakarta.

Tjasyono, B. 2004. Klimatologi. Institut Teknologi Bandung. Bandung.

Worasuharjo. 2004. Dasar-dasar Demografi. Fakultas Ekonomi Universitas Indonesia. Jakarta. 


\section{MIMBAR Agribisnis ISSN 2460-432I \\ Volume 1・Nomor 1 • Juli 2015}

